\title{
FEATURES OF REGIONAL IDENTITY FORMATION IN THE UK AND ITALY: COMPARATIVE ANALYSIS
}

\section{Rostetska S. I.}

\section{INTRODUCTION}

The current political processes in the countries of Europe as well as all over the world are characterized by increasing importance of the regional factor. At the same time, the concept of the region is complicated and not limited to geographical, ethnic and confessional borders. Regions are involved in international economic cooperation, unite in interregional associations, based on the principle of subsidiarity, support a diversity of self-interest, including not only economic, but often ethno-cultural, which go beyond one state. The formation and promotion of regional identity have become an integral part of the complex of international and foreign economic regional ties.

Each country is characterized by its own peculiarities of national identity formation policy based on regional identities. It is the interaction of regional identities within a single political space that may occur in different ways: the processes of ethno-linguistic and cultural synthesis are initially completely different regional identities; building a multicultural space around the core, central in the cultural and ethnic sense of the nucleus; finding a compromise between different ethnic and linguistic groups; the exclusion from the political order of the need to integrate regional identities into national unity while preserving their cultural and other identity, etc.

Active search for the foundations of identity, keen interest in the past country, attempts to define the content of such concepts as a citizen, nation - all these issues are actualized in modern society. Therefore, the purpose of this section is to provide a comparative analysis of the specifics of the process of regional identity formation in the Greater Yurian and Italian territories, countries with examples of devolution in the Center-Regions system, the existence of separatist tendencies and conflicts. 


\section{Features of regional identity in the UK}

With the increasing popularity of the ideas of globalism, the modern nation-state is experiencing a crisis of socio-political order. In recent decades, processes of political disintegration have emerged in many federal and unitary states of Western Europe. This process is particularly striking at present in the United Kingdom. Today, the UK is the only country in the world that fully adheres to its traditions, including in the political and political sphere, which is largely governed by customs. It is tradition that allows the English royal dynasty to still have strong power.

It has happened historically that the United Kingdom has been developing and becoming a centralized state. This development implied that the formation, first and foremost, of national identity ("Britishness") and the maximum weakening of Celtic regional (ethno-national) identities in the country.

However, it should be noted that this only weakened, but in no way destroyed, the regional identity of the Celtic periphery population. To date, "Scottish", "Welsh", "Irish" exist and develop as fully conscious identities, and which are supported by part of the population of the Celtic regions. An important feature of these regions and the communities that live there is that they identify not only as Scots, Welsh, Irish, but also emphasize their "Europeanness" as opposed to "British" affiliation.

For example, it is indicative that respondents across the United Kingdom identify themselves with their country of residence (region), that is, their priority is regional identity, not Britain as a whole. In figures, this is follows as: (60\% vs. 25). Yes, Scotland, according to 2014 , only $8 \%$ of respondents stated their British identity (in Wales, for example, $17 \%$ and in Northern Ireland $40 \%$ ). In terms of double selfidentification, $18 \%$ of Scots position themselves as such (for comparison, 7\% said in Wales, 9\% in England and 8\% in Northern Ireland) ${ }^{1}$. And important for further research is that for years these figures have not actually changed.

Speaking separately from the Celtic regions, most of Scotland's people feel, above all, Scots. At the same time, 94\% of those born in Scotland choose Scottish identity as the only or most important identity

\footnotetext{
${ }^{1}$ National identity and ethnicity in Scotland. ESRC Centre on dynamics of ethnicity. URL: http://www.ethnicity.ac.uk/medialibrary/briefings/dynamicsofdiversity/code-censusbriefing-national-identity-scotland.pdf (Accessed 23.05.2019).
} 
among other identities. The respondents describe "Scottishness" in very positive terms, pointing to the openness and loyalty of the society. In making a comparative analysis of Scottish and English identically, it is worth noting the traditional strength of Scottish and some weakness of English. In addition, Scots associate themselves with Europe (this can be explained by the absence of controversial factors), unlike in Britain, where the very notion of "Scots" - "British" causes controversy.

In Northern Ireland, the ideas of "Britishness" are extremely important to the Protestant part of the population, and Northern Irish Protestants can be called greater British patriots than Englishmen. But at the same time, most residents of Northern Ireland also call themselves Europeans. And in this sense Protestants and Catholics have a common position. paradoxically, it turns out that the "Britishness" of the Northern Irishman differs from the "Britishness" of the Englishman. In 2011, a fifth of the region's population identified itself as Northern Irish. In this respect, the situation has also improved in terms of relations between Protestants and Catholics, since in 1998 only up to $10 \%$ of Catholics declared their "Britishness". In 2014-2015, 29\% of the population identified themselves as Northern Irish, a quarter as Irish (25\%), 2/5 as British $(40 \%)^{2}$.

Speaking of Wales, 58\% of the population identify themselves exclusively as Welsh and only $7 \%$ call themselves both Welsh and British at the same time. The definition of "Welsh" is linked and based on knowledge of Welsh culture and Gaelic. Therefore, those who know and share Welsh culture and language are more likely to choose Welsh identity only and do not call themselves British. The Welsh also believe that they are, above all, Europeans, and later British ${ }^{3}$.

It is important that even the British themselves do not share the "Britishness". Of those, 3/5 say they are British, not British. Less than a tenth of England's population opt for a dual identity. $72 \%$ call themselves exclusively British, and $58 \%$ call themselves British rather than British ${ }^{4}$.

\footnotetext{
${ }^{2}$ Northern Ireland identity. URL: http://www.niassembly.gov.uk/globalassets/ documents/raise/knowledge_exchange/briefing_papers/series4/northern_ireland_identity_ga rry_mcnicholl_policy_document.pdf (accessed 16.05.2019).

${ }^{3}$ Welsh identity. URL: http://www.ethnicity.ac.uk/medialibrary/briefings/ dynamicsofdiversity/code-census-briefing-national-identity-wales.pdf (Accessed 10.05.2019).

4 English national identity. URL: http://www.walesonline.co.uk/news/walesnews/rise-english-national-identity-threatening-4880115 (Accessed 03.04.2019).
} 
It should be noted that "Englishness", unlike "Scottishness", "Welshness" and "Irishness", is already linked to Euroscepticism.

It is quite obvious that "Britishness" is undergoing a transformation, as both European and regional (including ethno-national) identities are influenced by it. Britain itself is undoubtedly linked to the country's history, expansion and world leadership. It is based on the unique geographical location of Britain, the constitution (in the form of collections of legislation), a rich history with the status of a maritime superpower. Thus, these factors construct British identity, and in times of crisis they always manifest themselves most strongly. The British themselves, decomposing "Britishness" into elements, indicate that its supports are Protestantism, empire, heavy industry (which in the past), but no new unifying elements are traced ${ }^{5}$. It was in the quest to preserve "Britishness" based on the democratic values and unity of the four nations (English, Scots, Welsh and Irish) that devotional models were developed. They were, in practice, supposed to confirm the existence of the fortress of the British Union and the readiness of the political system for democratic change.

There are three types of devolution in the theoretical dimension:

1) administrative - for example, setting up Government Offices in the regions, or, as it was before 1999, the practice of delegating powers from central government departments to the territorial ones of the same state;

2) executive - the exclusive rights of the United Kingdom Parliament are vested in the Ministries of Devolution Governments by statute;

3) Legislative - The United Kingdom Parliament delegates some of its powers to a subordinate legislature. Thus, the content of the legislative devolution lies in the creation of regional representative bodies (local parliaments, assemblies) that elect the population, and in granting them the right to "define policies and legislate" within the designated territories. That is, they are the supreme legislative authority with the power to resolve regional problems at the legislative level ${ }^{6}$.

${ }^{5}$ Hunt T. Labour must embrace Englishness // The Guardian. 5 February 2016. URL: https://www.theguardian.com/commentisfree/2016/feb/05/labour-embrace-englishnessproud-patriotism (Accessed 13.05.2019).

${ }^{6}$ Gerven W. Federalism in the US and Europe. ICL journal. 2007. Vol. 1. URL: http://www.internationalconstitutionallaw.net/journal. 
Devolutionary regulation in the United Kingdom is often characterized as asymmetric - there are significant differences between the arrangements in each country.

Note that with the introduction of the Declaration, the UK central government sought to block separatist tendencies in the regions (primarily in Scotland and Northern Ireland), to reduce political tensions between the center and the provinces by redistributing powers to the regions. This is what political leaders of regional movements sought to achieve. Thus, it is obvious that the British government's devolution was a kind of precautionary measure, a forced political step, a response to growing regional demands.

The essence of these devolution models is as follows. Following the referendums held in Scotland and Wales in September 1997, most voters supported the creation of a Scottish Parliament with the power to levy income tax and the National Assembly of Wales. In Northern Ireland, devolution was a central element of the Belfast Agreement, supported by referendums held in both Northern Ireland and the Republic of Ireland in May 1998. Following the referendums, Parliament adopted three legislation on devolution establishing the authorities with limited autonomy and defining the relevant powers - the Scotland Act (1998), the Northern Ireland Act (1998) and the Wales Government Act (1998). These legislative acts were subsequently amended, in particular, the Scotland Act (2012) extended the powers of the Parliament of Scotland, and the Government of Wales Act (2006) is now the central legislative body on which the Wales system is based. Elections to all legislatures with limited autonomy include an element of proportional representation, unlike the Westminster Parliament, whose members are elected by majority system.

The transfer and separation of powers differ in the three systems of limited autonomy. Foreign and defense issues remain at UK level, but instead there are a number of powers delegated to Scotland, Wales and Northern Ireland, in particular in the areas of agriculture, health and housing. At the same time, other powers, such as law enforcement and criminal justice, were transferred to Scotland and Northern Ireland but not to Wales. Local government issues are also the responsibility of the authorities of Scotland, Wales and Northern Ireland ${ }^{7}$. Thus, the principle

${ }^{7}$ The Implications of Devolution for England. URL: http://www.gov.uk/government/ publications (Acessed 17.05.2019). 
of dispersion in the UK is based on the principle of dispersion, in a sense of variational variance of management functions, depending on the specificity of the region. The model envisages the transfer of part of the power to the territorial level of the respective regions and the creation of an asymmetric model of governance, in which the regions are given specific functions and certain powers to regulate processes, especially in the sphere of economy and social relations, with the principle of clear limitation of the spheres of influence of the region power.

It should be noted that the peculiarities of devolution in the UK are due to the influence of internal and external factors, in the ratio of which the determining role belonged to internal factors.

Endogenous factors are related to the persistence of internal problems of the regions, uneven socio-economic development and the growing influence of the ethno-regional elite, which offers its own interpretation of the state of affairs and prospects for the development of the region.

External, exogenous factors are associated with processes such as globalization and European integration on the one hand, and differentiation and regionalization on the other.

In the context of globalization, the influence of the exogenous component is also increasing in the UK. The regions are beginning to act as agents of European politics and defenders of cultural heritage. On the one hand, the trend towards regionalization is increasing at the expense of the EU. For example, the Maastricht Treaty provided for the formation of a Committee of the Regions. Interregional cooperation financed by the Structural Funds has expanded. The new European Regional Strategy provided for funding and investment at the level of regions, but not states. On the other hand, the regions themselves show a desire to participate effectively in the implementation of their plans, not only at the regional but also at the European level, through the expansion of regional powers. Thus, the factors of globalization, Europeanization of socio-economic development, both state and ethnic regions in its composition, have a stimulating influence on regional and its kind of ethnic identity ${ }^{8}$. For the United Kingdom, European

8 Ерёмина Н.В. Факторы роста европейского этнорадикализма на примере Шотландской национальной партии и Североирландской партии «Шинн Фейн». Политическая экспертиза: ПОЛИТЭКС. 2010. Т. 6. № 1. С. 179-189. 
integration has become one of the problems of increasing national movements, and as a result of strengthening regional and ethnic identity. European integration has become a mainstay for ethnoregional communities since the mid-1970s, when they realized for themselves the financial and political appeal of the integration project. Communitarian policy, on the one hand, promotes the growth of ethnic nationalism and regionalism, but on the other hand, it promotes this movement into a more acceptable political and legal form and allows the concept of a "Europe of the Regions" to be attached to the construction of regional collective identity. It clearly demonstrated itself in the late 1990s. and at the beginning of the XXI century. The Charter of Regionalism, adopted by the European Parliament in 1988, as well as the Council of Communities and Regions of Europe and the Assembly of Regions of Europe, aiming at strengthening the political representation of regions at all levels, are aimed at acquiring ethnic regional minorities with the political protection of their identities.

Supporting European identity is represented not so much by the state as by the large groups of regions of these states, because they are interested in solving existing socio-economic problems at the expense of EU financial resources, as well as raising their status within the common European space. Therefore, in spite of the cultural peculiarities of the ethno-regional communities, they are, in the first place, ready to support European initiatives and call themselves Europeans.

It should be noted that it is important that the level of "Europeanness" is always higher where there is a sufficiently high level of awareness among the population of regional ethnic identity. For example, in the UK as a whole (especially in England) the notion of 'Europeanness' is often taken with caution, while in national regions, European integration is invariably endorsed. Scotland, Wales and Northern Ireland have opened their own offices in Brussels and are actively involved in the work of the Committee of the Regions and in the European Parliament. EU financial assistance to ethno-national regions of the United Kingdom is essential for their development. Especially great support is given to those regions that face a number of structural problems. For example, Wales received $€ 2.7$ billion in EU 
subsidies from 2014 to $2020^{9}$. 40. EUR 5 billion allocated to Scotland for the same period ${ }^{10}$. And about $€ 3.5$ billion has been earmarked for Northern Ireland ${ }^{11}$. The United Kingdom Government guarantees that all these payments will be maintained in the regions, even after the brutal Brexit to which the UK is preparing. However, the results of the Brexit referendum were not welcomed by the regions. And here not only the economic component. The referendum results have two dimensions: internal and external. Speaking of the internal dimension, firstly, Euroscepticism was and still is the prevailing idea over Eurooptimism in the political consciousness of the British. Secondly, it is the small parties that have formulated their position vis-à-vis the EU, avoiding a split. For example, the Scottish National Party has generally advocated maintaining EU membership. Thirdly, with the withdrawal of Britain from the EU, the norms of communication cease to exist. It also calls into question a number of constitutional acts, such as in the case of Northern Ireland, where the Republic of Ireland is a party. Fourthly, the exacerbation of London's relations with the Celtic regions, notably with Scotland, whose first minister, N. Sturgeon, held a decision in the Scottish Parliament on the second referendum on the region's independence in 2019, provided that Scotland will not be offered the compromise option of maintaining its links with the single European market. However, the Danish sample cannot be applied to Scotland, since in the case of Denmark, part of it (Greenland) is not part of the EU, while the situation in the United Kingdom is diametrically opposite. It is important that Northern Ireland will also need a similar reorganization and reformatting of interaction with the center.

Therefore, the United Kingdom with its four key regions is of particular interest in the context of the study of complex faults that are not limited by the line of separation between civic (British) and ethnic identity.

${ }^{9}$ EU funding in Wales. URL: http://gov.wales/funding/eu-funds/2014-2020/?lang=en (Accessed 23.05.2019).

10 EU funding in Scotland. URL: http://www.parliament.scot/ResearchBriefings AndFactsheets/S5/SB_16-89European_Union_Funding_in_Scotland_2014-2020.pdf (Accessed 25.05.2019).

${ }^{11}$ EU grants to Northern Ireland. URL: http://www.newsletter.co.uk/news/business/ where-do-eu-grants-to-northern-irelandgo-1-7233873 (Accessed 21.05.2019). 


\section{Specificity of formation of regional identity in Italy}

Under the Constitution, Italy is a unitary state, but in reality Italian unity is a rather shaky concept. The unification of the country under the auspices of the Piedmont monarchy happened a century and a half ago, but regional differences are still being traced.

First of all it is necessary to remember the historical past of the country. The late unification of Italy (on a scale of European history that took place just 150 years ago) played a direct role in what the current level of national and regional identities of the Italians is. The term "Risorgimento" is used to refer to the beginning of the formation and development of national consciousness. In today's Italian reality, there is still no consensus on the periodicisation of the process of the Risorgimento-National Liberation Revolution, which spanned much of the nineteenth century. Traditionally, the year of unification of Italy is considered 1861, but with many reservations. There is still debate over when exactly this process began, since even after the Congress of Vienna in 1815 the chances of unification were very slim: the very idea of the Italian nation seemed distant and not even particularly desirable to most Italians. Italy existed only as a geographical concept, and nothing more. And as Valerio Lintner rightly points out in his work Italy. The history of the country "in the process of Risorgimento and the unification of Italy can not see the historical inevitability caused by insurmountable forces. Rather, it was a series of unrelated and even accidental events that culminated in the creation of the historical and largely culturally logical and coherent unity we are now seeing ${ }^{12}$.

For many generations of Italian researchers, the key phrase was attributed to one of the creators of Risorgimento, an active participant in the process of political unification of the state of Massimo d'Adzello: "We created Italy, now we will create an Italian." This statement largely explains the relevance and importance of the problem of selfidentification at the time of territorial unification of the country.

Modern famous Italian specialist IB Levin on the subject writes the following: "Focusing on the absence of the Italian" in "already made" the only national-state space of the Italian Kingdom, Massimo d'Adzellio sent to the heritage of centuries-old fragmentation of the country, ... The call to "make Italian" was sometimes read as the need to end the

\footnotetext{
12 Линтнер В.Италия. История страны. М., 2008. С. 194.
} 
fragmentation of the territorial-administrative classification of the inhabitants of the peninsula. In addition, the country was divided into many provinces and municipalities: by the time of unification, it had 7721 cities (in neighboring France twice as many as 1,307), with which 713 date back to the evenings of 1971 and to the Roman era (not coincidentally the medieval metaphor of Italy was the "country of cities"). Not every of these settlements was the center, capital, citadel of something - duchy, county, abbey, etc. -and jealously oversaw his own orders, traditions, customs ${ }^{13}$.

For example, in language. In the years of Risorgimento, only one resident of forty could speak the so-called standard Italian - the other thirty-nine spoke local dialects. Common to all languages, created on the basis of the Florentine dialect of Dante and Boccaccio, was able to suppress (but not supplant) only the spread of radio and television, but linguistic unity has not yet been achieved. Any resident of the country is able to determine one or two phrases without fail, from which area and even from which city his interlocutor comes. It is often the case that as soon as one Italian switches from the standard language to his dialect, the interlocutor ceases to understand it.

The language differences are not limited. Many residents of Italy perceive themselves primarily as Venetians or Neapolitans, and only in the second - as Italians. Administratively, the country is divided into twenty regions, but there is another, informal division into the North and South. The North is rich so much that living standards are virtually inferior to Northern Europe. Against this background, the South looks to be another country: income levels in Calabria, Campania, Apulia and Sicily are twice lower than in Lombardy, Veneto and Emilia Romagna.

In a very simplified form, the existing economic division of Italy can be drawn to the following picture: there is a dynamic industrial and financial center in the North and a semi-agrarian inert periphery in the South.

The claims that Southerners and Northerners make to each other is a long story. The process, which in the North was regarded as the

13 Левин И.Б. Национальная идентичность в условиях глобализации (на материале Италии) // Новые тенденции во внутренней политике развитых стран. М., 2005. C. 89. 
unification of Italy, was perceived by many in the South as the illegal conquest of the Kingdom of both Sicily Piedmont (a brilliant account of this point of view was given by Tommaso di Lampedusa in Leopard). Mussolini's attempt to forge a single nation from the inhabitants of the Apennine Peninsula, the heir to the Roman Empire, was unsuccessful and left a bad memory.

In Italy, as in the world as a whole, the region is becoming an important level of political and economic dialogue, where national, supranational and global forces meet local requirements.

One of the acute problems that is closely linked to regional identity is the problem of separatism in Italy.

According to the Italian Constitution, five regions have specific forms and conditions of autonomy: Friuli-Venezia Giulia, Sardinia, Sicily, Trentino-Alto Adige and Valle d'Aosta. These regions have the highest political and economic importance among all the administrativeterritorial units of the Italian state. They have the most pronounced and separatist sentiment. This is primarily due to historical reasons. For example, much of the province of Friuli-Venezia Giulia adjacent to Trieste was transferred to Yugoslavia after World War II. Ethnic and linguistic Slovenian minorities are distinguished from a number of linguistic minorities. In the Trentino-Alto Adige region, which includes the autonomous provinces of Trento and Bolzano, about $70 \%$ of the inhabitants are ethnic Germans, because previously these territories were part of the Austro-Hungarian Empire. After the First World War, under the Treaty of Saint-Germain, Trentino and the Southern Triol moved to the Italian Kingdom.

In Sicily, the Party for the Autonomy Movement operates, headed by the governor of the region R. Lombardo. The party is represented, albeit poorly, in both houses of the Italian Parliament. Its center-right program does not go beyond broad economic and political autonomy. There is also a more radical party in Sicily, the Movimento per l'Indipendenza della Sicilia (MIS), which originated from the Sicilian independence movement of 1943-1947. decolonization, self-determination, independence and the struggle against Italian politics in Sicily. The 
impact of these organizations is currently small ${ }^{14}$. In Valle d'Aosta since 1948, Franco-Italian bilingualism has been officially recognized, with French fulfilling its statutory and representative function. Meanwhile, sociological research conducted in 2011 found a significant advantage in favor of the Italian language. According to the results of the polls, $71.58 \%$ of respondents called it their native language, $12.16 \%$ of the respondents speak different dialects / dialects, 3.21\% speak French, $0.99 \%$ speak French. The same identifier for the region is the FrancoProvencal speeches. The very notion of "speech" (Fr. Patois) in Valle d'Aosta lost its negative connotation; on the contrary, speech is called "the language of the heart," which implies a particular attachment of the Waldostants to their native speech ${ }^{15}$.

In Sardinia, for many years there has been a movement for independence from Italy and any other state (Indipendentismu SARDU). Its development is due to the fact that, as his ideologues insist, Sardinian culture is significantly different from Italian, and also with the threat of the gradual disappearance of the Sardinian language. In addition, a group called "CantonMaritimo" ("Maritime Canton") was created on the social network Facebook, which aims to annex Sardinia to Switzerland. It expresses the position of the Sardinian Party of Action. A. Caruso, one of the founders of the movement, proposes to transfer the island of Switzerland as compensation for public debt, as the officially recognized unemployment rate on the island is $18.1 \%$. Back in 2012, a poll showed that $40 \%$ of Sardinians would vote for separation from Italy. ${ }^{16}$

The main qualitative indicator that distinguishes separatist movements in Italy, and moreover, is how influential and active are the associations and their ideas. At present, separatist movements have a strong influence on areas in the northern part of the country. This is primarily due to economic factors: for example, the unemployment rate in

14 Баранов А.В. Сепаратизм в современной Италии: факторы развития, институционализация, политические стратегии. Человек. Сообщество. Управление. 2015. T. 16. № 12. С. 85.

${ }_{15}$ Моисеева Д.П. Валле-д’Аоста на перекрестке языков и идентичностей. Россия u Запад: диалог культур. 2015. № 8. URL: http://www.regionalstudies.ru/ journal/homejornal/rubric/2012-11-02-22-11-32/366-q-q.html (Дата обращения: 23.05.2019).

16 Баранов А.В. Сепаратизм в современной Италии: факторы развития, институционализация, политические стратегии. Человек. Сообщество. Управление. 2015. T. 16. № 12. С. 87. 
Italy in March 2016 was $11.4 \%$, and in the south, for example, in Sicily, the unemployment rate is twice as high as the national average. That is why the inhabitants of the north consider themselves as "producers" and the southern regions as "consumers", and consider it more profitable to create a state without the southern regions.

The growing discontent of the North towards the South led to the creation of the Northern League for the Independence of Padania (Lega Nord per l'Indipendenza della Padania). The League of the North was created in 1989. It advocates the creation of an independent state falling with the capital in Milan by giving the northern provinces independence from the agrarian South. There are two trends in the programming documents of the League of the North: on the one hand, it emphasizes the belonging of the northern regions (Padania) to European identity and their active participation in the global economy; from the outside. One of the basic principles proposed by the League of the North is the point about the creation of tax federalism. In general, the ideology and political actions of the League of the North did not lead to a serious threat to the national unity and territorial integrity of Italy. At the same time, they have made a significant contribution to the process of a certain transformation of the country's political system in the EU, namely the process of "devolution", ie the transfer of broader administrative and financial powers from the central government to the regions ${ }^{17}$. The results of the 2018 parliamentary elections in Italy have shown that Eurosceptics have widespread support in society. And it was the League of the North, which changed its political power to the League, received a large percentage of the vote. The parliamentary elections stipulated that the electors voted simultaneously for both the lower house and the senators. According to the results of the Senate elections, the rightmost populists from the "League of the North" are Matteo Salvini, Forza Italy ("Forward, Italy") Silvio Berlusconi and the National Conservative Party "Brothers of Italy". Second place - using the left slogans of the Five Star protest movement with Luigi di Mayo (over 32 percent). The Social Democrats came in third with almost 23 percent of the vote. In the

${ }^{17}$ Giorgia Bull and Filippo Tronconi. The elusive nature of the Lega Nord // Mapping the Extreme Right in Contemporary Europe: From Local to Transnational / Andrea Mammone, Emmanuel Godin, Brian Jenkins. Routledge, 2012. P. 123. 
lower house of the parliament, center-right leaders lead by 37 percent of the vote, 32.7 percent in the Five Star Movement, and the Social Democrats gain about 23 percent (with the ruling Democratic Party at the same time, about 19 percent) ${ }^{18}$.

Moreover, a new government was formed in Italy - three months after the election, which led to a strange alliance of the Left 5 Star Movement with right-wing League populists. At first glance, there is little in common between the two political forces, but weeks of intense negotiations have shown that ideological opponents can reach a compromise on key foreign and domestic policy issues. Their compromise was consolidated by a coalition agreement of fifty pages. It specifies, in particular, the desire of both parties to support the lifting of EU sanctions against the Russian Federation, as well as to refrain from restrictive measures in the EU economy. Another important agreement was that the party leaders did not apply for the post of Prime Minister Matteo Salvini (League) and Luigi di Mayo (5 Star Movement). As a result of the negotiations, the choice suddenly fell to little-known Florence law professor Giuseppe Conte - a man who had never worked in public office before. But the coalition did not last long. The crisis in the activity was the vote of the League together with the opposition for the construction of high-speed rail in France, this was contrary to the position of the Five Star Movement. In Italy, the populist Five Star Movement and the center-left Democratic Party have said they have agreed to form a coalition government. The parties have agreed that Giuseppe Conte will remain as Prime Minister.

Italy has only confirmed the trend: more radical rivals of the traditional parties are becoming an acceptable choice for Europeans who see in their populist slogans and promises an alternative and novelty. Europeans expect simple solutions from them for complex problems that have accumulated over the years.

Thus, we can conclude with an understanding of regional specificity that the most in-depth and comprehensive understanding of the complex mechanism of self-determination of Italians is possible only through the prism of the national-regional component.

18 Elezioni Politiche 2018. URL: .https://www.corriere.it/elezioni-2018/risultatipolitiche/camera.shtml?refresh_ce-cp 


\section{CONCLUSIONS}

Regions play an increasingly important role in geopolitical processes. Problems of regionalism are at the center of political life in many countries today.

Regional identities have their complex structure and dynamics, characterized by sub-regional cleavages within the very regional identities that are defined by the ethnic minorities formed in the process of immigration. In the context of globalization, the latter circumstance, especially in the sense of increasing in recent years the flow of immigrants from the Middle East and other regions of the world, contributes to the formation of various ethnic differences within the regional identities, which actualizes the problem of social and political consolidation in the devotional regions. Brexit, in turn, raised the question not only of "Britishness" in relation to regional identities, but also of the need for further constitutional changes in the country in the context of deepening devolution.

With regard to Italy, despite the large number of different separatist movements and their active activities, none of them succeeded in achieving the goals and bypassing the Italian constitution. It should be noted that the situation of national and linguistic minorities in the country cannot be called critical, since they represent their interests in the Parliament (both in the Senate and in the House of Deputies). Persistence in the actions of separatist movements is linked to their deep historical roots. A possible catalyst for movements could be the problem of influxes of refugees from the Middle East, as in the UK. The huge influx of migrants will worsen the socio-economic situation in the country, which will increase the number of supporters of various separatist movements. At some point, the central government may not keep the situation under control, and it is difficult to be sure that Italy will long be able to exist as a single state.

And finally, a positive point for the EU may be that Italian Eurosceptic populists do not put on the agenda the question of Italy's exit from the EU following the example of the British.

The very conventionality of Italian unity reduces the severity of the controversy between the Federalists and the Unitarians and guarantees that Italy's political passions will not reach the same level as in the United Kingdom. For Scots, Northern Irish, the struggle for secession is a matter of national-regional identity, not tax redistribution. In Italy, the attempts 
of individual regions to change relations with the center are mainly due to economic considerations, so a simple redistribution of powers in their favor will be sufficient to preserve the unity of the country, albeit on other federal grounds.

\section{SUMMARY}

This section of the monograph focuses on the consideration of identification processes within the framework of regional identity formation in the United Kingdom and Italy.

Comprehensive analysis of the components that form regional (national-regional) identity in Italy and the United Kingdom has been carried out. The study takes into account the context of both the historical legacy and the current globalization processes, which undoubtedly play an important role in constructing a model of regional identity of any state.

Within the framework of political decentralization in both the UK and Italy, a devolution model has been implemented, the content and features of the current stage of devolution in these countries have been revealed, the essence of which is to choose a model and political strategy for the transition to a larger-scale strategy of expanding the sphere of selfgovernment of regions and their participation in the adoption. political decisions.

It is shown that the factors of globalization, European regionalization have a stimulating influence on the development of the system of state management of socio-economic development of both the state and its ethnic regions.

The attention was paid to the presence of separatist movements in these countries, the main reasons for their development and the level of influence on the present political space of the studied states were determined.

\section{REFERENCES}

1. Баранов А.В. Сепаратизм в современной Италии: факторы развития, институционализация, политические стратегии. Человек. Сообщество. Управление. 2015. Т. 16. № 12. С. 78-90.

2. Ерёмина Н.В. Факторы роста европейского этнорадикализма на примере Шотландской национальной партии и Североирландской партии «Шинн Фейн». Политическая экспертиза: ПОЛИТЭКС. 2010. T. 6. № 1. С. 179-189. 
3. Левин И.Б. Национальная идентичность в условиях глобализации (на материале Италии) // Новые тенденции во внутренней политике развитых стран. М., 2005. С.85-94.

4. Линтнер В. Италия. История страны. М., 2008. 372 с.

5. Моисеева Д.П. Валле-д'Аоста на перекрестке языков и идентичностей. Россия и Запад: диалог культур. 2015. № 8. URL: http://www.regionalstudies.ru/journal/homejornal/rubric/2012-11-02-2211-32/366 (Дата обращения: 23.05.2019).

6. Elezioni Politiche 2018. URL: https://www.corriere.it/elezioni2018/risultati-politiche/camera.shtml?refresh_ce-cp 25.05.2019).

7. English national identity. URL: http://www.walesonline.co.uk/ news/wales-news/rise-english-national-identity-threatening-4880115 (Accessed 03.04.2019).

8. EU funding in Wales. URL: http://gov.wales/funding/eufunds/2014-2020/?lang=en (Accessed 23.05.2019).

9. EU funding in Scotland. URL: http://www.parliament.scot/ ResearchBriefingsAndFactsheets/S5/SB_16-

89European_Union_Funding_in_Scotland_2014-2020.pdf (Accessed 25.05.2019).

10. EU grants to Northern Ireland. URL: http://www.newsletter.co.uk/news/business/where-do-eu-grants-tonorthern-irelandgo-1-7233873 (Accessed 21.05.2019).

11. Gerven W. Federalism in the US and Europe. ICL journal. 2007. Vol. 1. URL: http://www.internationalconstitutionallaw.net/journal.

12. Giorgia Bull and Filippo Tronconi. The elusive nature of the Lega Nord // Mapping the Extreme Right in Contemporary Europe: From Local to Transnational / Andrea Mammone, Emmanuel Godin, Brian Jenkins. Routledge, 2012. 344 p.

13. Hunt T. Labour must embrace Englishness // The Guardian. 5 February 2016. URL: https://www.theguardian.com/commentisfree/ 2016/feb/05/labour-embrace-englishness-proud-patriotism (Accessed 13.05.2019).

14. National identity and ethnicity in Scotland. ESRC Centre on dynamics of ethnicity. URL: http://www.ethnicity.ac.uk/medialibrary/ briefings/dynamicsofdiversity/code-census-briefing-national-identityscotland.pdf (Accessed 23. 05. 2019). 
15. Northern Ireland identity. URL: http://www.niassembly.gov.uk/ globalassets/documents/raise/knowledge_exchange/briefing_papers/series 4/northern_ireland_identity_garry_mcnicholl_policy_document.pdf (Acessed 16.05.2019).

16. The Implications of Devolution for England. http://www.gov.uk/government/publications (Acessed 17.05.2019).

17. Welsh identity. URL: http://www.ethnicity.ac.uk/medialibrary/ briefings/dynamicsofdiversity/code-census-briefing-national-identitywales.pdf (Accessed 10.05.2019).

\section{Information about the author: Rostetska S. I.}

Candidate of Political Sciences, Associate Professor of the Department of Political Sciences and Law, South Ukrainian National Pedagogical University named after K. D. Ushynsky 26, Starofrankivska str., Odessa, 65000, Ukraine 